\title{
Barriers to ICT use in EFL teacher education courses in Nepal: An activity theory perspective
}

\author{
Suman Laudari and Damian Maher \\ University of Technology Sydney (UTS)
}

\begin{abstract}
The effectiveness of pre-service teachers' ICT training during teacher education course is often linked with the teacher educators' (TEs') practices. TEs' digital practices, however, are under-studied, thus, are not fully understood. This study, which draws on the theoretical tenets of Activity Theory, reports on the factors that limit TEs' digital practices in a context where technology use has just begun to evolve. Using a multi-method case study, this study collected data from EFL TEs and policymakers. The analyses of the policy data and interviews reveal that multiple factors constrain TEs' digital practices. A key finding of the study is that factors related to ICT policies, training for TEs and resources hindered the use of technology by TEs. Implications of these are discussed.
\end{abstract}

Keywords: ICT, barriers, EFL teacher education, Activity Theory, contradictions

\section{Introduction}

Information communication technologies (ICT) is argued to enhance access, equity, and quality in learning and teaching. Thus, there has been a call for the seamless use of educational technologies in teaching and learning (e.g. Balanskat, Blamire, \& Kefala, 2006; UNESCO, 2016). Following a surge in technology use in education internationally, ICT has been one of the components of educational planning in Nepal. For example, the $10^{\text {th }}$ Five Development Plan, 2002 exclusively mentioned that computer literacy would be introduced at all levels in school (Nepal Planning Commission, 2002). Likewise, the National Curriculum
Framework (Government of Nepal Ministry of Education, 2005) advised teachers to make maximum use of ICT in lesson planning and in pedagogical activities to facilitate teaching and learning. Lately, the school level curriculum also urged teachers to make use of ICT for teaching and learning (Government of Nepal Ministry of Education, 2014).

To promote technology use in education, Ministry of Education Nepal (MoE) implemented a five year long ICT project called 'ICT in Education' in 2013 (Government of Nepal Ministry of Education, 2013). The project aimed to address the issues of accessibility and 
discrepancies in quality through the use of digital technologies. In implementing the project, MoE trained select groups of teachers and teacher trainers on the pedagogical use of technologies, and those professionals were entrusted to cascade training to other teachers in the schools.

In continuation of emphasising ICT use in education, MoE listed digital skills as one of the eight competencies of qualified teachers in the 'Teacher Competency Framework-2016'. It stated that a professionally competent teacher coulduse ICTs for effective teaching and learning (Government of Nepal Ministry of Education, 2016). An underlying assumption of the framework isthat graduating teacher will have developed the technological skills alongside pedagogical and content knowledge when they enter the service.

Another implication of the TeacherCompetency Framework is that teacher educators (TEs) have the required competencies to teach with ICTs, and they integrate technologies in teaching and learning. That is because only when TEs integrate technologies, can the future teachers get opportunities to experience technology use. However, as technology use has just started to emerge, it is necessary to understand whether TEs use digital technologies; and what factors impact their practices. To that end, this study set out to investigate teacher educators' digital practices, learning and competencies. In this paper, we report on the factors that influence TEs' practice. The research question that this study answered is:

\author{
How do different factors impact EFL \\ teacher educators' digital use in \\ teacher education courses?
}

\section{Review of literature}

When an educator decides to use technology, she/he has to negotiate the different factors. Whilst some factors facilitate technology use, others inhibit. The factors that constrain technology use are called barriers, and they have been classified in different ways in the literature.

One such classificationidentifies barriers as first-order and second-order (Ertmer, 1999, 2005). The first-order barriers are the ones external to teachers and include resources (software and hardware), planning/preparation time, and administrative and technological support. The second-order barriers are internal and are associated with teachers' beliefs, motivation and attitude (Ertmer, Ottenbreit-Leftwich, Sadik, Sendurur, \& Sendurur, 2012).

Through time and with more studies in the field, more specific categories of barriers have been proposed. Such categories comprise resources, training and technological support, institutional vision and support, knowledge, skills and attitude, and curriculum design and assessment (Drent \& Meelissen, 2008; Francom, 2016; Hew \& Brush, 2007; Kopcha, 2012). Likewise, other factors, such as time (Blundell, Lee, \& Nykvist, 2016; Ertmer \& Ottenbreit-Leftwich, 2010), teachers' beliefs, and institutional support (Francom, 2016; Vasinda, Ryter, Hathcock, \& Wang, 2017), ICT policies, 
funding, and ongoing training opportunities for teachers (Hamel, Turcotte, \& Laferrière, 2013; Laferrière, Hamel, \& Searson, 2013) have also been identified to impact technology use in classrooms.

With the increased funding and decreasing technology costs, access to technologies has improved now compared to early/ mid-2000s. Therefore, authors (Ertmer et al., 2012) aver that first-order barriers to technology are less noticeable, and second-order barriers are becoming more influential. This argument has been supported by different studies (e.g. Blau \& Shamir-Inbal, 2017; Ertmer \& Ottenbreit-Leftwich, 2010; Ertmer et al., 2012; Kim, Kim, Lee, Spector, \& DeMeester, 2013; Smarkola, 2008; Tondeur, van Braak, Ertmer, \& Ottenbreit-Leftwich, 2017; Vasinda et al., 2017) as they have established that teachers' technology practices in pedagogical activities are influenced by ICT related attitude, beliefs and skills.

However, in the studies emerging from the developing or least developed countries, the narratives still strongly focus on external barriers. Thus, studies emerging from such contexts have reported that first-order barriers are still pervasive in ICT integration. For example, Albugarni and Ahmed (2015) reported that there were issues of space, access to resources, ICT support system, and training to teachers in integrating technology in Saudi Arab. Likewise, a study by Cunningham (2015) noted that factors such as institutional policies, ICT training to lecturers, infrastructures and lack of context suitable e-content hindered technology integration efforts in Kenyan universities. Similarly, AlAzawei, Parslow, and Lundqvist (2016) concluded that factors relating to resources (internet connection and power outage), insufficient finance, lack of training and technical support and policy imprecision deterred the implementation of e-learning system in public universities in Iraq. Research studies based in Tanzania (Mwakyusa \& Mwalyagile, 2016), Indonesia (Lim \& Pannen, 2012), and Egypt (Sobaih \& Moustafa, 2016) also identified the issues discussed above as barriers.

As regards to the South Asian context, search for literature yielded a limited number of empirical studies. An opinion paper by Khan, Hossain, Hasan, and Clement (2012) in the context of Bangladesh reported that lack of finance, infrastructure, policies, corruption, and political commitment were the major barriers to ICT integration. While a study from Pakistan by Qureshi, Ilyas, Yasmin, and Whitty (2012) also identified infrastructure as a constraining factor, it further reported that there were issues of privacy, technical assistance, and English language competencies that constrained the use of e-learning platform in Pakistani universities.

The review of studies in this section suggests that there exists a dichotomous narrative in research on barriers to technology use; while studies in techaffluent countries are more focused on teacher-internal factors, narratives emerging from developing or least developed economies reveal that the first-order barriers deter ICT integration efforts. 


\section{Theoretical framework}

The theoretical framework that undergirds this study is Activity Theory and its construct of contradictions (Engeström, 2000; Engeström \& Miettinen, 1999). 'Activity Theory' (AT) holds that various contexts surround usin learning and living; thus, those contextual factors inform and influence one's practice (Terpstra, 2015). In using AT, this study considers that a TE's technological practices are influenced by the realities of the community (classroom, institution and educational stakeholders such as university Grants Commission and Ministry of Education). Therefore, when the early adopters of technologies start using technologies in their practice, their actions do not align with the normal course of the community. As results, opportunities and tensions arise. While opportunities facilitate TEs' practices, tensions constraint the efforts of teacher educators.

Those tensions are contradictions and expose themselves as obstacles, interruptions, misfit, conflicts and caveats (Engeström, 2001). However, they are not problems (Tay, Lim, \& Lim, 2013) as they seed changes and developments (Engeström \& Miettinen, 1999). They are inevitable because activity systems continuously work through contradictions, which occur between its different constituents or with external activity systems.

The constituents of an activity system are subject or an actor; their motive for action, which is called object; the tools that mediate the subject's actions within his/her community with stratified roles/ duties for the activity regulated by overt and coverts norms and standards, which are known as rules.

Four levels of contradictions have been identified based on their nature. They are primary, secondary, tertiary and quaternary (Engestrom, 1987). While the primary contradiction occurs within the elements of an activity system, a secondary contradiction occurs between the elements of the activity system. Tertiary contradictions "arise when activity participants face situations where they have to use an advanced method to achieve an objective" (Gedera, 2016, p. 58). The quaternary contradictions occur between the primary and the secondary activity systems. Recognition of contradictions in the activity system directs the focus to the origin of the disturbances, resolving which can result in changes (Engeström, 2000). Blundell et al. (2016) employed the contradiction as mechanisms and identified external barriers to technology use in teachers' technological practices. Laferrière et al. (2013) also used contradictions to recognise and resolve tensions while integrating technologies in classrooms.

\section{Methodology}

The study presented here is a part of a larger ongoing PhD study. The underpinning methodology is a case study which uses multi-methods to collect data (Stake, 2005; Yin, 2015). This paperis based on the review of some key educational policy documents (discussed in Section 5.1), and interview data from two policymakers and 22 TEs that were early adopters of technologies. The TEs 
came from 17 different teacher education campuses (TECs) in urban, semi-urban and regional cities of Nepal. Their teaching experiences ranged from 6 years to 26 years, and they taught in public, private and community-owned TECs. The policymakers were the Dean of two teacher education campuses, and they influenced the EFL teacher education policies across all kinds of campuses. These respondents were selected purposively based on two factors: whether they used any technologies in teaching and learning; and their intention to participate in the study.

Two rounds of semi-structured interviews were conducted with the TEs to uncover their technology-related beliefs and ICT practices. The average length of the interview in the first phase was about 50 minutes and 30 minutes in the second phase. The second-round interviews were conducted only after the data from the first phase were categorised into different themes, and the analysis was underway.

The interviews, most of which were conducted in Nepali, were translated, transcribed and checked for accuracy before importing them on to NVivo, 11.4, for analyses. Following Patton (2015) and Merriam and Tisdell (2016), the data were analysed using thematic content analyses methods. For the coding of the data, while somea-priori themes from the literature were used, others emerged from the data. The data were read wordfor-word and coded into categories. Once the categories were developed, and the analyses process started, five TEs were interviewed a second time, where they were briefed about the categories and the findings. All the TEs confirmed the findings and provided further information to substantiate their earlier narratives. Their agreement added to the confidence in the analysis.

The policy documents were also imported into NVivo and read to find the discussion on technology integration in teacher education. While policy documents were useful in understanding context, the evidence from such dossiers was used to corroborate the interview data from the teacher educators and the policymakers.

\section{Findings and discussion}

The analyses of the data showed that the use of technologies by early-adopter-TEs did not align with their realities. Thus, there were opportunities and tensions. The tensions, which have been classified as barriers, were of both external and internal nature. Given the limitations in the space, in this paper, we discuss only the external barriers. Seventeen extrinsic factors, which influenced their digital practice, were noticed in the TEs' narrations. Based on the patterns in the interview, they have been listed in the categories as summarised in the table below: 
Table 1: List of external barriers as stated by TEs

\begin{tabular}{|c|c|}
\hline Categories & Sub-categories \\
\hline Resources & $\begin{array}{l}\text { Locally designed/produced digital content }(3)^{*} \\
\text { Lack of financial resources (9) } \\
\text { Lack of ICT infrastructure (Computer lab, power- } \\
\text { supply, internet connection, multimedia projector, } \\
\text { and display board) (15) } \\
\text { Low internet speed (6) } \\
\text { No technical Support (5) } \\
\text { Lack of time for preparing lesson and digital content } \\
\text { (9) } \\
\text { Security of infrastructure (2) }\end{array}$ \\
\hline Training & Not enough training on technology use (19) \\
\hline Assessment & Nature of assessment (15) \\
\hline Curriculum & No curriculum on technology use in EFL course (3) \\
\hline Policy & $\begin{array}{l}\text { No written documents or policy guidelines on } \\
\text { technology use specific to EFL teacher education (6) }\end{array}$ \\
\hline Administration-related & $\begin{array}{l}\text { Supporting and facilitating TEs' ICT use (12) } \\
\text { Political intervention influencing ICT investment } \\
\text { and programmes (3) } \\
\text { Corruption in infrastructure procurement process (2) }\end{array}$ \\
\hline Student-related & $\begin{array}{l}\text { Students' socio-economic background (5) } \\
\text { No internet subscription and suitable ICT device (10) } \\
\text { Students' lacking ICT knowledge and skills (9) }\end{array}$ \\
\hline
\end{tabular}

*The numbers in the parentheses refer to the number of TEs who discussed those issues during the interview 


\section{Quaternary contradiction: Policies versus technology use}

In this study, the process of policy design and implementation was considered to be a separate activity system because educational agencies or stakeholders outside TECs did the policy design and implementation. Therefore, policymaking was identified as a neighbouring activity system to the primary activity system, which is ICT integrations in teacher education. While TEs were expected to use technologies in their pedagogical practices, as stated at the outset of the paper, the policy documents did not have enough guidelines on technology use in teacher education courses. In that sense, quaternary contradictions existed between policies and technology use.

For example, during the review of Higher Education Policy, a key document in higher education in Nepal, it was noticed that one of the objectives of higher education is to help the graduates enhance their digital skills, which they can leverage when they enter the workforce(Government of Nepal Ministry of Education, 2015). Likewise, the document identifies digital technologies to be a mechanism to enhance quality in education to remain competitive internationally. When such statements are coupled with the policy changes in school education, as discussed in the introduction, it can be noticed that educators in higher education are expected to use technologies.
The expectations for TEs to use technologies were also reflected in the interviews with the policymaker. During the interview, the head of a programme at the public university stated that the TEs were provided ICT training on the operation of the computer, use of PowerPoint and screen recording. He further stated that the TEs were provided with personal devices for the pedagogical use and multimedia projectors were made available in the classrooms for teaching and learning activities.

The Dean of the private university also stated that they aimed to enhance technology use. A key feature of their teacher education programme was the use of a learning management system (LMS). The Dean noted that they aimed to blend their course and promote student-centred pedagogies through the use of technology. Therefore, they had some general guidelines which discussed their technology use policies.

However, both universities and their campuses (constituent and affiliated) had limited policy documents that specified how and why technologies should be part of teacher education courses. For example, when asked if the university had standards for its teaching staff and pre-service teachers, the Dean responded:

"I think, what you just did was not just ask questions but also made me aware that the university has to think from that perspectives as well... I feel, [they] have the know-how knowledge. However, as for the independent use of technology, how capable they are, 
and what skills they have, we have never thought from that perspective."

Likewise, there were no any nationallevel professional standards for teacher educators, teachers or graduating teachers regarding ICT use despite the competency identified digital competencies as a core skill required for teaching (see, Government of Nepal Ministry of Education, 2016). This lack of documentation on technology use in teacher education was also noted by (Dhakal \& Pant, 2016) in a review of university policies on ICT use.

Policies on technology use in education are of high significance because they impact all aspects of technology integration in education (Drent \& Meelissen, 2008; Varvel, Montague, \& Estabrook, 2007) and provide reasons for effective uptake of ICTs (Phuong, Cole, \& Zarestky, 2018; Zhu, 2015). Therefore, the lack of policy was found to have farreaching consequences. For example, infrastructure, training and technical support, which are prerequisites of seamless integration of ICTs, were limited in many campuses because the campuses were not required to ensure those as there was no policy. While these have been discussed in greater length in ensuing sections, lack of these resources resulted in secondary contradictions in the EFL TEs' technology use activity system because they constrained their technology practice.

In our opinion, while the imprecision in policies provided some TEs with opportunities to become creative, not all of them knew what they could do with the digital resources at their disposal.
They did not have guidance on what ICT skills pre-service teachers were required to learn by the end of the programme. Because policies provide guidance and reasons for technology use (Adnan \& Tondeur, 2018), a lack of those meant that the tools that the TEs used were based on their discretion. In that sense, limited and unclear policies created tensions (i.e. contradictions) in TEs' technological practices as TEs did not have a pathway to follow, and that resulted in the use of ICT to support traditional practices rather than to enhance teaching/learning experiences. Therefore, limited policies gave rise to quaternary contradictions in the ICT integration process.

\section{Secondary Contradictions}

As can be seen from the Table- 1 above, many external issues influenced TEs' technology use. When those factors were considered relative to Activity Theory, some secondary contradictions were identified in TEs' digital practices. They have been discussed below.

\section{Resources versus ICT use}

It was clear through the data that multiple issues related to resources constrained the EFL TEs' use of technology in their lessons. The most pervasive resource-related issue was the lack of infrastructure. At least 15 TEs stated that there were not enough resources required to use technologies at the TECs where they taught. For example, TE1 noted, "In general, the access is not very good...the department does not have a personal desk and computer for teachers' use... [neither is 
there] internet facility for teachers and students' use." In a similar vein, TE16 said, "...we do not have the physical infrastructure required to use technology. For example, we do not have computers, PowerPoint projector, wiring and power supply in the classroom." Likewise, TE24 stated, "the classrooms are not equipped with ICT devices, and the electricity keeps going off unexpectedly...we not have a backup system." Like these three TEs, their counterparts also stated that the lack of infrastructure deterred their intentions to use technologies.

As the data illustrates, most TECs did not have the required resources to encourage technology use. Physical infrastructure is a necessary condition for the successful use of digital technologies (Searson, Laferriere, \& Nikolow, 2011). Without physical resources, seamless integration of technologies in educational practices is unthinkable (Hew \& Brush, 2007). For example, TE6, TE8 and TE18, who taught at constituent campuses noted that they did not use any technologies in their lessons because their TECs did not even have a multimedia projector for general use. So, they gave lectures without using any digital aids.

The analysis of the data also showed that resource-related issues were related to the paucity of required financial resources. Both policymakers and TEs also stated that they did not have enough financial resources at their TECs to set up computer labs, connect to the internet and provide other support that required money. For example, the head of the programme from the public university and the Ministry of Education noted that they were not able to expand ICT facilities due to economic constraints as setting up initial ICT infrastructure and its uptake requires noteworthy investment. In a similar vein, TE17, who worked part-time in a community campus (affiliated to the public university) maintained:

"In the...college where I teach, they
have financial constraints as they
solely rely on student fees. So, even
if they wish, they cannot buy ICT
tools. That is because they even
struggle to pay the salary to the
teachers and the staff.

Discussing the impact of lack of finance in infrastructure, TE5 noted that the campus was not able to purchase a highspeed internet because they did not have economic resources to do so. Inability to expand the available services due to financial issues influenced how, where, and when technologies were used. For instance, TE2, TE3, TE4 and TE5 said that they could not browse and multimedia content in the classroom because they did not have a consistent and reliable internet connection at their TECs unless they downloaded such content before the class, at home. This meant that the TEs were required to work extra hours in finding and getting such downloading such content for offline viewing.

The issue of lack of time was compounded by the lack of relevant econtent and resources for the courses that they taught. So, the TEs were required to do everything from scratch. For example, TE14 noted that "the lack of locally created e-content (such as 
videos) influenced the technology practice of teacher educators because the teachers need to spend much time in preparation."

Additionally, nine TEs also noted that they had limited time to prepare digital content at the campus because many of the TEs were casuals. As they taught a large number of classes every day, they had few hours for lesson preparation. That resulted in secondary contradiction in their digital practice because they did not have time to prepare lessons. Usually, when a teacher or a TE decides to use technology in a lesson, they are required to spend a considerable amount of time previewing the sources and preparing digital materials and content to use in the lesson (Hew \& Brush, 2007; Quadri, Muhammed, Sanober, Qureshi, \& Shah, 2017). Therefore, when they are not provided time for lesson preparation during their office hours, they need to sacrifice their personal time in lesson preparation.

The lack of time created secondary contradictions in TEs' practices. That is because a teacher educator, who spends hours preparing their lessons or setting up a learning management system, pays a personal price in reviewing the webbased sources and preparing the lessons.Such experiences can result into the feelings of 'burn out' in teachers (Hew \& Brush, 2007) and create contradictions in their practice (Blundell et al., 2016) and deter the efforts of technology integration (Quadri et al., 2017; Skues \& Cunningham, 2013; Tarus, Gichoya, \& Muumbo, 2015).

In overall, the findings substantiate the argument that technological resources of different nature have a pivotal role in the successful use of technologies in the educational institutions (Lim \& Pannen, 2012; Quadri et al., 2017). The availability of resources on campus influenced the extent of on-campus and in-class technology use by teacher educators in teaching and learning. Not having enough financial resources to spend on infrastructure, access and other necessary conditions for technology use meant that the TEs could not execute activities that required the use of the internet and other digital technologies on campus. Those tensions manifested as secondary contradictions in TEs' digital practices and negatively influenced TEs' technology use.

\section{Training versus technology use}

The next issue that influenced TEs' practice was training related to using technologies in educational practices. Eighteen TEs stated that they had received no training through the university or the TECs. That gave rise to secondary contradictions in the activity system and influenced technology use by the TEs.

Of the 19 TEs from the public university, only four from the central campus reported having attended some training on technology use through the university. Others were unaware of any training on technology use. For example, TE8, who taught at a regional constituent campus, said, "I have never attended any training at the university." Because there were no locally-designed, needbased professional development opportunities, the TEs believed they lacked skills and confidence. Even the 
most exemplary users of digital technologies noted that they lacked confidence and wished they knew more. For instance, TE6 said, "I wish I had skills related to [using different] software, such as photo and video editing; such skills would help me develop good instructional materials." Along the same line, TE4 noted, "I wish that there was more [training]... that would encourage us to use technologies more often in better ways."

Because TEs' technology skills were selftaught, they had limitations in what they could do. Therefore, they avoided using technologies when they did not feel confident. For example, TE20, who taught phonetics and phonology in an affiliated campus, avoided using PowerPoint presentation despite not wishing to do so because he said, "the [phonetic] symbols did not display clearly...and, it was difficult to draw them on PowerPoint slides." Likewise, TE11 avoided using technologies whenever he had to draw any table or diagram on PowerPoint slides because he did not know how to do that.

These data illustrated that TEs' skills to use ICT in education were self-taught, which however had its limitations. For example, as discussed above, TEs avoided technology use when they faced a task which was beyond their existing knowledge and skills. As they lacked need-based professional development opportunities, they could not expand their digital expertise and resulted in primary contradictions in their use of technology use. As a result of such contradictions, they avoided the use of technologies when they believed they did not have the required skills.
The data above suggest that teachers need a well-developed pedagogy knowledge and skill base to draw upon when deciding to use technologies in their practice and those develop from (Hew \& Brush, 2007; Hughes, Liu, \& Lim, 2016). Such skills can develop when TEs are provided meaningful support in the form of training at the campus (Garrison \& Akyol, 2009). As TEs did not have opportunities for ICT related professional development activities, the TEs' technological expertise was limited, and that influenced their practice.

\section{Assessment versus technology use}

A top-down approach to assessment system was found to have influenced how the teacher educators and the preservice teachers used technology. The assessment system gave rise to secondary contradictions in TEs' technology use and influence the extent, frequency and the process of technology use in teaching and learning.

At least 15 TEs stated that they needed to consider the exams and course coverage when planning to use digitally enabled pedagogical activities in the class. For example, TE2 said:

\section{"... as the course load is very heavy, and students need to prepare for exams, ICT based project that I discussed goes only for a couple of weeks in an academic year. If I made my entire classes project-based, then Iwon't be able to cover the content in the curriculum".}

In the same vein, TE3 noted that the exams and syllabus influenced the way he used technologies. He said, 
"...because we have content load and limited time...the focus is on completing the course [rather than] discussion on using ICT in the EFL classroom."

On a different note, TE9 commented that he used PowerPoint presentation because the tools helped him cover a wide content area and finish the lessons in limited time. Fourteen other TEs also expressed similar concerns/opinions regarding when and how they used technologies. What was common in the TEs' discussion was that exam-focused teaching/learning activities impacted their practice.

The findings substantiate the argument that when teachers are made to follow externally set assessment system, that can limit the extent and the process of technology use (Butzin, 2004; Hew \& Brush, 2007). As TEs considered the issue of course coverage and exam preparation when they planned technology use, the nature of the exam impacted how and when they used those tools as in the case of TE2, TE9 or TE3. As the exam-driven system did not let them use technologies more effectively, for example, to enhance teaching/learning practice, there were secondary contradictions between assessment system and TEs' technology use.

\section{Administrative Issues versus technology use}

The other issues that impacted TEs' use of technologies were related to the TECs' administration. During the analyses of the TEs' narrations, it was noticed that such issues gave rise to contradictions in TEs' technological practices because lack of support from administrative staff deterred technology use on campus.

The TEs, mostly those teaching in the constituent and the central campuses of the public university, noted that some people in the administration did not fully comprehend the value of technology use in educational activities. Therefore, they did not provide support to TEs or cared for the maintenance of existing facilities. For example, TE1 noted, "when we say ICT, they usually think that it is a onetime hardware installation. There is no investment in maintenance, support and training...they usually do not care about that." In keeping with his counterpart, TE4 noted, "[they are] not concerned about whether the available facilities are working properly. For example, there is a Wi-Fi for general use...but nobody cares whether it is working." He further noted that the people concerned lacked willingness and commitment to promote ICT use in education.

Furthermore, TE6 and TE15 believed that some administrative staff were not much concerned about pedagogical activities, so they did not provide the necessary support. In explaining their argument, they argued that some officials in the administration were recruited based on political recommendations. Therefore, they were more concerned about political agenda and monetary benefit than enhancing the teaching/learning environment, including ICT integration. TE12, who is a veteran TE, agreed to his counterparts and averred that the as long as political interests were prioritised over academic activities, there would be issues of ICT infrastructure, access and support. 
While the issue of political intervention impacting ICT integration has not been discussed in the literature, the issue of corruption has also been identified by Khan et al. (2012) in the context of Bangladesh. They argued that pervasive corruption problem influenced technology integration efforts in the Bangladeshi education system. When these issues are coupled with administrative officials' digital illiteracy and lack of motivation, TEs' lack the support from the TECs' administration. That, in turn, deter TEs' ICT integration effort.

\section{Students-related issues versus technology use}

The TEs' also stated that there were issues related to students that sometimes impacted their efforts to integrate technologies. Such constraints were identified to be secondary contradictions in the ICT integration activity system.

It was noted in at ten TEs' interview data that their students did not have personal internet subscription or personal devices because they could not afford to purchase laptops, high-end smartphones or personal internet subscriptions. Therefore, whenever TEs planned to use technologies, they were required to consider whether most of their students could complete their tasks. This resulted in secondary contradictions as it impacted their efforts to use ICT in their practice. For example, TE5 maintained:

The other challenge, the major one, is students' access to the Internet and ICT tools. Teachers' efforts will not be effective unless students have good access. For example, I have enrolled all my students in the Moodle...I want them to participate in discussion but they cannot because they do not have a computer or internet subscription.

As the quote illustrates, technology integration efforts were influenced by students' financial abilities to afford digital tools.

Some TEs also noted that because their students lacked access to ICT, they did not have the necessary ICT skills required to use digital tools, and that influenced ICT integration in lessons. For example, TE11 noted, "some of [my] students are not even aware that they can use Google for information search and resources." Likewise, TE18 said, "I do not always use ICTs because [some] students show a lack of interest in ICT...they do not have good computer skills." That is so because, as TE3, TE4 and TE5 commented, their students never experienced any use of technologies in their prior degrees and they did not have personal access to technological resources. Because students' lacked knowledge, skills and confidence and did not show interests in the use of technologies, TEs' could not integrate ICT tools effectively despite having interests.

The findings in this section illustrate that students' abilities to afford personal resources and their ICT skills influence the instructional design of TEs (PorrasHernández \& Salinas-Amescua, 2013). Because students' lacked skills and tools, they could not complete the tasks set by TEs. Those issues influenced TEs' ICT integration efforts. 


\section{Conclusion and recommenda- tions}

This article shed light on the factors that influenced technology use in the EFL teacher education courses in the teacher education institutes in Nepal. Through the discussion, it was established that various external factors impacted how, where, and when TEs used technologies during teaching and learning. Those issues created tensions that manifested as quaternary, secondary or primary contradictions in the ICT integration activity systems.

Because contradictions seed development and change (Engeström \& Meittinen, 1999), these findings have policy and pedagogical implications. Firstly, the findings have highlighted that several external challenges need to be addressed if the stakeholders aim to enhance ICT integration in EFL teacher education courses. Some of those barriers are prerequisites to technology use. For example, without the necessary physical infrastructure, seamless use of ICT across a course remains out of questions. Therefore, the TECs have to seek financial resources, and the stakeholders need to provide economic and technical support to resolve resource-related issues.

Secondly, higher education policies need to reflect the changes regarding technology use in high schools, so that the TECs and administrators realise that technology use needs to be promoted. Thirdly, when policies, such as ICT standards for TEs and graduating teachers, are in place, the TEs know if they need to enhance their skills and how technology should be used.
Next, the teacher education stakeholders need to understand that technology integration does not happen just by introducing a stand-alone module; technologies have to be embedded seamlessly in all subjects. Only then the graduating teachers gain technological pedagogical and content knowledge, which are now core competencies of qualified high school teachers in Nepal (Government of Nepal Ministry of Education, 2016).

Furthermore, the universities and the TECs need to identify their curricular needs related to ICT and provide ongoing professional development opportunities to the TEs to enhance and expand their use of ICT. For that, the TECs can organise sharing sessions amongst the TEs so that the educators can share what they know with others. An example of that is the TEs can identify educators with excellent ICT skills and have them deliver training to TEs. All of these will be useful in enhancing their skills and expanding their uses.

Lastly, as this study is a part of a larger study, which is a work on progress, other aspects of teacher educators' digital practices will be discussed in other papers. However, we believe that a longitudinal study that employs digital ethnography design may be able to uncover a detailed and more comprehensive picture of TEs' digital practice and their impact on the learning of pre-service teachers.

\section{References}

Adnan, M., \& Tondeur, J. (2018). Preparing the next generation for effective technology integration in education: 
Teacher educators' perspective. Paper presented at the EdMedia + Innovate Learning Conference, June 25-29, 2018, Amsterdam, Netherlands. Retrieved from https:// www.researchgate.net/publication/ 326113362.

Al-Azawei, A., Parslow, P., \& Lundqvist, K. (2016). Barriers and opportunities of e-Learning implementation in Iraq: A case of public universities. The International Review of Research in Open and Distributed Learning, 17(5), 126146.

Albugarni, S., \& Ahmed, V. (2015). Success factors for ICT implementation in Saudi secondary schools: From the perspective of ICT directors, head teachers, teachers and students. International Journal of Education and Development using Information and Communication Technology, 11(1), 36.

Balanskat, A., Blamire, R., \& Kefala, S. (2006). The ICT impact report. A review of studies of ICT impact on schools in Europe, 11.

Blau, I., \& Shamir-Inbal, T. (2017). Digital competences and long-term ICT integration in school culture: The perspective of elementary school leaders. Education and Information Technologies, 22(3), 769-787.

Blundell, C., Lee, K.-T., \& Nykvist, S. S. (2016). Digital learning in schools: Conceptualizing the challenges and influences on teacher practice. Journal of Information Technology Education, 15, 535-560. doi:https://doi.org/ $10.28945 / 3578$

Butzin, S. (2004). Project CHILD: A proven model for the integration of computer and curriculum in the elementary classroom. Asia-Pacific Collaborative education Journal, 1(1), 29-34.

Cunningham, M. (2015). Factors impacting on adoption of technology-enhanced learning techniques by universities in
Nairobi, Kenya. Paper presented at the Technology and Society (ISTAS), 2015 IEEE International Symposium on.

Dhakal, R. K., \& Pant, B. P. (2016). Assessment of teacher education curricula in Nepal: An ICT perspective. International Journal of Innovation, Creativity and Change, 2(3), 96-108.

Drent, M., \& Meelissen, M. (2008). Which factors obstruct or stimulate teacher educators to use ICT innovatively? Computers E Education, 51(1), 187-199.

Engestrom, Y. (1987). Learning by expanding. Helsinki: Orienta-Konsultit Oy.

Engeström, Y. (2000). Activity theory as a framework for analyzing and redesigning work. Ergonomics, 43(7), 960-974.

Engeström, Y. (2001). Expansive learning at work: Toward an activity theoretical reconceptualization. Journal of Education and Work, 14(1), 133-156.

Engeström, Y., \& Meittinen, R. (1999). Activity theory and individual and social transformation. In $\mathrm{Y}$. Engeström, R. Miettinen, \& R.-L. Punamäki (Eds.), Perspectives on activity theory (pp. 19-38). Cambridge: Cambridge University Press.

Engeström, Y., \& Miettinen, R. (1999). Introduction. In Y. Engeström, R. Miettinen, \& R.-L. Punamäki (Eds.), Perspectives on activity theory (pp. 118). Cambridge:: Cambridge University Press.

Ertmer, P. A. (1999). Addressing first-and second-order barriers to change: Strategies for technology integration. Educational Technology Research and Development, 47(4), 47-61.

Ertmer, P. A. (2005). Teacher pedagogical beliefs: The final frontier in our quest for technology integration? Educational Technology Research and Development, 53(4), 25-39. 
Ertmer, P. A., \& Ottenbreit-Leftwich, A. T. (2010). Teacher technology change: How knowledge, confidence, beliefs, and culture intersect. Journal of Research on Technology in Education, 42(3), 255-284.

Ertmer, P. A., Ottenbreit-Leftwich, A. T., Sadik, O., Sendurur, E., \& Sendurur, P. (2012). Teacher beliefs and technology integration practices: A critical relationship. Computers $\mathcal{E}$ Education, 59(2), 423-435.

Francom, G. M. (2016). Barriers to technology use in large and small school districts. Journal of Information Technology Education: Research, 15, 577-591. doi:https://doi.org/ $10.28945 / 3596$

Garrison, D. R., \& Akyol, Z. (2009). Role of instructional technology in the transformation of higher education. Journal of Computing in Higher Education, 21(1), 1042-1726.

Gedera, D. S. (2016). The application of activity theory in identifying contradictions in a university blended learning course. In D. S. Gedera \& P. J. Williams (Eds.), Activity theory in education: Research and practice. Netherlands: Sense Publishers.

Government of Nepal Ministry of Education. (2005). National curriculum framework for school education (Preprimary-12) in Nepal. Bhaktapur: Curriculum Development Center, Nepal.

Government of Nepal Ministry of Education. (2013). Information $\mathcal{E}$ Communication Technology (ICT) in education: Master Plan 2013-2017. Kathmandu: Department of Information, Nepal Government.

Government of Nepal Ministry of Education. (2014). Secondary School Curriculum (Class 9-10), 2014. Bhaktapur: Curriculum Development Center, Nepal.
Government of Nepal Ministry of Education. (2015). Higher Education Policy-2015. Kathmandu, Nepal: Education Press. Retrieved from http://www.moe.gov.np/article/ $691 /$ higher-education-policy2072.html.

Government of Nepal Ministry of Education. (2016). Teacher Competency Framework. National Center for Educational Development, Sanothimi, Bhaktapur. Retrieved from http:// nced.gov.no.

Hamel, C., Turcotte, S., \& Laferrière, T. (2013). Evolution of the conditions for successful innovation in remote networked schools. International Education Studies, 6(3), 1-14.

Hew, K. F., \& Brush, T. (2007). Integrating technology into K-12 teaching and learning: Current knowledge gaps and recommendations for future research. Educational Technology Research and Development, 55(3), 223252.

Hughes, J. E., Liu, S., \& Lim, M. (2016). Technological modeling: Faculty use of technologies in preservice teacher education from 2004 to 2012. Contemporary Issues in Technology and Teacher Education, 16(2), 184-207.

Khan, M., Hossain, S., Hasan, M., \& Clement, C. K. (2012). Barriers to the introduction of ICT into education in developing countries: The example of Bangladesh. Online Submission, 5(2), 61-80.

Kim, C., Kim, M. K., Lee, C., Spector, J. M., \& DeMeester, K. (2013). Teacher beliefs and technology integration. Teaching and Teacher Education, 29, 7685.

Kopcha, T. J. (2012). Teachers' perceptions of the barriers to technology integration and practices with technology under situated 
professional development. Computers $\mathcal{E}$ Education, 59(4), 1109-1121.

Laferrière, T., Hamel, C., \& Searson, M. (2013). Barriers to successful implementation of technology integration in educational settings: A case study. Journal of Computer Assisted Learning, 29(5), 463-473.

Lim, C. P., \& Pannen, P. (2012). Building the capacity of Indonesian education universities for ICT in pre-service teacher education: A case study of a strategic planning exercise. Australasian Journal of Educational Technology, 28(6).

Merriam, S. B., \& Tisdell, E. J. (2016). Qualitative research: A guide to design and implementation (4th ed.). San Francisco, CA: Jossey-Bass.

Mwakyusa, W. P., \& Mwalyagile, N. V. (2016). Impediments of e-learning adoption in higher learning institutions of Tanzania: An empirical review. Journal of Education and Practice, 7(30), 152-160.

Nepal Planning Commission. (2002). Tenth five year development plan. Kathmandu, Nepal: Department of Information, Nepal Government.

Patton, M. Q. (2015). Qualitative Research $\mathcal{E}$ Evaluation Methods: Integrating Theory and Practice (4th ed.). London: Sage.

Phuong, T. T., Cole, S. C., \& Zarestky, J. (2018). A systematic literature review of faculty development for teacher educators. Higher Education Research $\mathcal{E}$ Development, 37(2), 373-389. doi:10.1080/07294360.2017.1351423

Porras-Hernández, L. H., \& SalinasAmescua, B. (2013). Strengthening TPACK: A broader notion of context and the use of teacher's narratives to reveal knowledge construction. Journal of Educational Computing Research, 48(2), 223-244.

Quadri, N. N., Muhammed, A., Sanober, S., Qureshi, M. R. N., \& Shah, A. (2017).
Barriers effecting successful implementation of e-Learning in Saudi Arabian universities. International Journal of Emerging Technologies in Learning (iJET), 12(06), 94-107.

Qureshi, I. A., Ilyas, K., Yasmin, R., \& Whitty, M. (2012). Challenges of implementing e-learning in a Pakistani university. Knowledge Management $\mathcal{E}$ E-Learning: An International Journal (KMEEL), 4(3), 310-324.

Searson, M., Laferriere, T., \& Nikolow, R. (2011). Barriers to successful implementation of technology integration in educational settings. Communication présentée au EduSummIT, Paris. Récupéré de: http:// edusummit. nl/res2011/ calltoaction2011/briefpapers 2011.

Skues, J. L., \& Cunningham, E. (2013). The role of e learning coaches in Australian secondary schools. Journal of Computer Assisted Learning, 29(2), 179-187.

Smarkola, C. (2008). Efficacy of a planned behavior model: Beliefs that contribute to computer usage intentions of student teachers and experienced teachers. Computers in Human Behavior, 24(3), 1196-1215.

Sobaih, A. E. E., \& Moustafa, M. A. (2016). Speaking the same language: the value of social networking sites for hospitality and tourism higher education in Egypt. Journal of Hospitality $\mathcal{E}$ Tourism Education, 28(1), 21-31.

Stake, R. E. (2005). Qualitative Case Studies. In N. K. Denzin \& Y.S. Lincoln (Eds.), The Sage Handbook of Qualitative Research (3rd ed., pp. 443-466). Thousand Oaks, California: SAGE Publications.

Tarus, J. K., Gichoya, D., \& Muumbo, A. (2015). Challenges of implementing elearning in Kenya: A case of Kenyan public universities. The International 
Review of Research in Open and Distributed Learning, 16(1).

Tay, L. Y., Lim, S. K., \& Lim, C. P. (2013). Factors affecting the ICT integration and implementation of one-to-one computing learning environment in a primary school-A sociocultural perspective. In L. Y. Tay \& C. P. Lim (Eds.), Creating holistic technologyenhanced learning experiences: Tales from a future school in Singapore (pp. 1937). Rotterdam, The Netherlands: Sense Publisher.

Terpstra, M. (2015). TPACKtivity: an activity-theory lens for examining TPACK development. In C. Angeli \& N. Valanides (Eds.), Technological pedagogical content knowledge (pp. 6388). Rotterdam, The Netherlands: Springer.

Tondeur, J., van Braak, J., Ertmer, P. A., \& Ottenbreit-Leftwich, A. (2017). Understanding the relationship between teachers' pedagogical beliefs and technology use in education: a systematic review of qualitative evidence. Educational Technology Research and Development, 65(3), 555575.

UNESCO. (2016). ICT in Education. France: UNESCO.

Varvel, V. E., Montague, R. A., \& Estabrook, L. S. (2007). Policy and e-learning. In R. Andrews \& C. Haythornthwaite (Eds.), The Sage handbook of e-learning research (pp. 269-285). Thousand Oaks, CA: SAGE Publications.

Vasinda, S., Ryter, D. A., Hathcock, S., \& Wang, Q. (2017). Access is not enough: A collaborative autoethnographic study of affordances and challenges of teacher educators' iPad integration in elementary education methods courses. Contemporary Issues in Technology and Teacher Education, 17(3), 411-431.
Yin, R. K. (2015). Case study research : design and methods (5th ed.). LA: Sage.

Zhu, C. (2015). Organisational culture and technology-enhanced innovation in higher education. Technology, Pedagogy and Education, 24(1), 65-79. doi:10.1080/1475939X.2013.822414

Contributors: Suman Laudari, $\mathrm{PhD}$, is a learning designer and technology specialist at Institute of Interactive Media and Learning (IML), University of Technology Sydney (UTS), Australia. His research interests include ICT in education, the role of agency and beliefs in pedagogical practices of ICT, motivation in second language learning and teaching.

Damian Maher, EdD, is a senior lecturer at University of Technology Sydney (UTS), Australia. He specialises in teaching and research in technology use in education. His current area of research is on the use of digital technologies in both primary and secondary schools and on teaching and learning in the tertiary sector. The use of spaces to support learning, both physical and online and the ethical implications of this are areas Damian is investigating. He is also interested in project-based learning and how this is being implemented in schools. 